\title{
Validating the Scale of the New Ecological Paradigm (NEP) in Brazilian University
}

\section{Students}

\author{
Validando a Escala do Novo Paradigma Ecológico (NEP) em Estudantes Universitários Brasileiros \\ Validación de la escala del Nuevo Paradigma Ecológico (NEP) en Estudiantes Universitarios
}

Brasileños

Received: 03/16/2021 | Reviewed: 03/22/2021 | Accept: 03/27/2021 | Published: 04/04/2021

\author{
José Francisco dos Reis Neto \\ ORCID: https://orcid.org/0000-0002-1152-1149 \\ Universidade Anhanguera Uniderp, Brazil \\ E-mail: jose.rneto@ anhanguera.com \\ Celso Correia de Souza \\ ORCID: https://orcid.org/0000-0002-2689-8264 \\ Universidade Anhanguera Uniderp, Brazil \\ E-mail: csouza939@gmail.com \\ Taner Douglas Alves Bitencourt \\ ORCID: https://orcid.org/0000-0002-1501-8567 \\ Universidade Anhanguera Uniderp, Brazil \\ E-mail: taner.bitencourt@anhanguera.com \\ Cristiano Miranda Cupertino \\ ORCID: https://orcid.org/0000-0002-9989-4985 \\ Faculdade Pitágoras de Maceió, Brazil \\ E-mail: cristiano.cupertino@kroton.com.br \\ Patrício Lauro de Melo Neto \\ ORCID: https://orcid.org/0000-0003-0587-5597 \\ Faculdade de Ciências Sociais Aplicadas de Sinop, Brazil \\ E-mail: patricio.neto@kroton.com.br \\ Davi Guimarães Soares \\ ORCID: https://orcid.org/0000-0003-0965-3019 \\ Universidade Anhanguera Uniderp, Brazil \\ E-mail: davigsoares@hotmail.com \\ Iara de Oliveira Rodrigues \\ ORCID: https://orcid.org/0000-0002-6778-110X \\ Universidade Estadual do Mato Grosso do Sul, Brazil \\ E-mail:adm_iara@hotmail.com
}

\begin{abstract}
This article brings within two purposes. First it validated the scale of the New Ecological Paradigm (NEP) and then analyzed the ecocentrist and anthropocentric attitudes of university students from a Brazilian higher education institution. The original NPE scale of 15 items was used, in the form of a questionnaire and applied in a sample of 241 university students. Before the self-completion of the questionnaires, the university students did not receive the basic concepts of environmental attitudes. Confirmatory factor analysis techniques were used to test the structural model and statistical procedures to describe the sample as to its properties of similarities between the groups of students. The NEP was reduced to 13 items, proving to be reliable and valid to investigate structured and multidimensional environmental attitudes of university students. When analyzing the segmentation of university students, it was identified that women presented a more intense ecocentrist attitude than men. For the other segmentation groups in relation to age range, area of knowledge, semester in progress and course period, they did not present statistically significant differences. However, overall, the scores of university students indicated more ecocentrist than anthropocentrist attitudes. The convenience sample of part of the courses offered by the higher education institution may cause a bias in the research, considering as a limitation of this study. However, with the confirmation of the twofactor model, the results indicate consistency and guide future research to activities related to the environment, such as sustainable tourism, preservation against environmental impacts, among others.
\end{abstract}

Keywords: Pro-environmental attitude; Attitude of university students; Anthropocentrism; Ecocentrism; Brazil.

\section{Resumo}

O propósito deste artigo foi duplo. Primeiro validou a escala do Novo Paradigma Ecológico (NEP) e depois analisou as atitudes ecocentristas e antropocentrista de estudantes universitários de uma instituição de ensino superior brasileira. Foi utilizado a escala original do NPE de 15 itens, na forma de um questionário e aplicado em uma amostra 
de 241 universitários. Antes do autopreenchimento dos questionários, os universitários não receberam os conceitos básicos as atitudes ambientais. Foram utilizadas técnicas de análise fatorial confirmatória para testar o modelo estrutural e de procedimentos estatísticos para descrever a amostra quanto as suas propriedades de semelhanças entre os grupos de acadêmicos. O NEP foi reduzido para 13 itens, mostrando-se confiável e válida para investigar atitudes ambientais estruturadas e multidimensionais de estudantes universitários. Quando analisado a segmentação dos universitários foi identificado que as mulheres apresentaram uma atitude ecocentrista mais intensa do que os homens. Para os demais grupos de segmentação em relação a faixa de idade, área de conhecimento, semestre em curso e período do curso, não apresentaram diferenças estatisticamente significante. No entanto, no geral, a pontuação dos universitários indicou atitudes mais ecocentrista do que antropocentrista. A amostra por conveniência de parte dos cursos oferecidos pela IES pode causar um viés na pesquisa, considerando-se como uma limitação deste estudo. No entanto, com a confirmação do modelo de dois fatores, os resultados indicam consistência e orientam para pesquisas futuras às atividades relacionadas ao meio ambiente, como turismo sustentável, preservação contra impactos ambientais, dentre outras.

Palavras-chave: Atitude pró-ambiental; Atitude de universitários; Antropocentrismo; Ecocentrismo; Brasil.

\section{Resumen}

El propósito de este artículo era doble. Primero validó la escala Nuevo Paradigma Ecológico (NEP) y luego analizó las actitudes ecocéntricas y antropocéntricas de estudiantes universitarios en una institución de educación superior brasileña. Se utilizó la escala NPE original de 15 ítems, en forma de cuestionario y aplicada a una muestra de 241 estudiantes universitarios. Antes de los cuestionarios auto-completados, los estudiantes universitarios no recibieron los conceptos básicos y las actitudes ambientales. Se utilizaron técnicas de análisis factorial confirmatorio para probar el modelo estructural y los procedimientos estadísticos para describir la muestra con respecto a sus propiedades de similitudes entre grupos de académicos. El NEP se redujo a 13 ítems, demostrando ser confiable y válido para investigar actitudes ambientales estructuradas y multidimensionales de estudiantes universitarios. Al analizar la segmentación de los estudiantes universitarios, se identificó que las mujeres tenían una actitud ecocéntrica más intensa que los hombres. Para los otros grupos de segmentación en relación a rango de edad, área de conocimiento, semestre en curso y período del curso, no hubo diferencias estadísticamente significativas. Sin embargo, en general, las puntuaciones de los estudiantes indicaron actitudes que eran más ecocéntricas que antropocéntricas. La muestra de conveniencia de parte de los cursos que ofrece la IES puede generar un sesgo en la investigación, considerándolo como una limitación de este estudio. Sin embargo, con la confirmación del modelo de dos factores, los resultados indican consistencia y orientan futuras investigaciones hacia actividades relacionadas con el medio ambiente, como el turismo sostenible, la preservación frente a impactos ambientales, entre otras.

Palabras clave: Actitud proambiental; Actitud de los estudiantes universitarios; Antropocentrismo; Ecocentrismo; Brasil.

\section{Introduction}

The environment is at the heart of contemporary issues. It is interest goes beyond the limits of Brazil, becoming an international discussion. Since the 1960s a group of scientists have debated and presented a report on the limits of growth (Meadows et al. 1973), alerting to its relationship between the economy and the environment (Nascimento, 2008). The discussion of environmental preservation and its relationship with economics, were strengthened by the following events: in 1972 with the Stockholm conference; in 1987 with the Brundtland report and with the dissemination of the concept of sustainable development and eco-development (Sachs, 2008); in 1992 with the conference of Rio de Janeiro; in 1997 with the Kyoto Protocol; and in 2012 with the UN Conference Rio +20; as highlighted by Mikhailova (2004), Nascimento (2008) and Nossa et al., 2017) .

Considering these movements, a change in environmental paradigms was noticed by people and companies. Development and protection of the environment were adjusted to the term of sustainable development, under the mandatory precepts related to the integrated dimensions of environmental, social, economic, political, cultural, and territorial (Sachs, 2008). It was perceived the incorporation of interests and responsibilities with the environment, both macro and micro, by involving the environmental attitudes of people directed to sustainability (Faber et al., 2005; Costa et al., 2019). The concept of sustainable development can be considered from the United Nations report in which it states that: "Humanity has the ability to make sustainable development to ensure that it meets the needs of the present without compromising the ability of future generations to meet their own needs." (Brundtland, 1988); and the most recent one, proposed by Holden et al. (2017) in which 
sustainable development is a system of normative values, in perfect harmony and interacted with human rights, democracy and freedom. Thus, sustainable development is essentially a strong ethical and moral pronouncement as to what should be done, commented by Nossa et al. (2017).

Until the mid-1970s, the current paradigm, in much of society, was related to environmental protection policies, a view under the concept of the dominant social paradigm (DSP). This explained the perceptions of society in harnessing the environment to meet its needs (Dunlap et al. 1978). These authors then argued that the fundamental view of the environment was changing, as was society's relationship with nature. They conceptualized what they called the New Environmental Paradigm, such as understanding the ability of people, society, and companies to interfere in the balance of nature. A belief in what are the limits of environmental exploitation in meeting the growth needs of human society (Dunlap et al., 2000).

Dunlap and Van Liere (1978) initially presented an instrument with twelve items (declarations), representing a single scale to conceive the attitude of society in transition from the DSP to a new more environment (Anderson, 2012). The initial scale model was revised and adjusted to fifteen statements (Dunlap et al., 2000). It was named New Ecological Paradigm (NEP), with eight unique statements, which were accepted by the interviewees reflect acceptance for NEP, that is, indicative of a pro-ecological view, or ecocentric vision. The other seven peer statements representing endorsement of the DSP, a disagreement with the pro-ecological view, or an anthropocentric view, as world design. Dunlap et al. (2000) stated that revised NEP was more consistent and better validated to measure the population's view of the environment. The fifteen declarations of this items are presented in Table 2.

This NEP scale is widely used to assess environmental attitudes in various groups of people in various parts of the world (Dunlap, 2008). The NEP scale was used in association with other scales for the determination of pro-environment attitudes: populations (Edorgan, 2009; Guedes et al., 2012; Moyano-Days \& Palomo-Vélez, 2014; Hsu \& Lin, 2015; Ntanos et al., 2019), environmental education (Teixeira et al., 2016), agri-industry actions (Schinaider \& Talamini, 2019), tourism (Kim et al., 2006; Luo \& Deng, 2008; Giddy \& Webb, 2018), behavior of university students (Sutton \& Gyuris, 2015; Utari \& Nadiroh, 2016; Speer et al., 2020; Barros et al., 2020), actions for the conservation of species (Hunter \& Rinner, 2004), among other academic productions, national and international.

Supported by these literatures, the research aimed to validate the scale of the New Ecological Paradigm, with the use of structural equation modeling and obtain an empirical description of attitudes towards the environment of university students of a Higher Education Institution (HEI). Its properties of similarities or differences between different groups (gender, age group, area of knowledge, semester in progress, and period of classes) were explored regarding their anthropocentric or ecocentrism attitude.

\section{Methodology}

The research approach was quantitative, considering that it provides the possibility of generalizing some aspects found in the research, in obtaining a significant sample and in the representative of the studied population. Also, quantitative research allows the implementation of statistical tests and analysis of the validity of the results found (Gerhardt \& Silveira, 2009; Pereira, Shitsuka, Parreira, \& Shitsuka, 2018)

To test the conceptual model and other relationships, a questionnaire was elaborated and divided into two sections: the first, the NEP scale declarations and the second, the academic profile. The NEP was used to measure the values on ecological attitudes, through 15 items proposed by Dunlap et al. (2000). The declarations were translated from English into Portuguese and compared with the scale translated by Guedes et al. (2012). Then, three university professors in the environment area made their comments and suggested minor modifications to the final instrument. The items were measured using a 7-point Agreement Likert scale, coded from $1=$ Totally disagree to $7=$ totally agree, while $4=$ Neutral. It should be noted that, 
originally, Dunlap et al. (2000) used a 5-point Likert measurement scale. Following the ideas proposed by Dunlap et al. (2000), of the 15 statements, the eight even items are intended to reflect support for the ecocentrist attitude (ECO), while agreement with the other seven odd items represent endorsement of the dominant social paradigm, or anthropocentrism (ANTRO). Or in the opposite way, the disagreement with the seven odd items indicates a proecological worldview. A second section was used to establish the profile of the undergraduate student, regarding his/her gender, level of education, age, city of residence, undergraduate course, semester of the course and period of the course.

The questionnaire was applied during the month of May 2019, in an intensional and cross-sectional sample of undergraduate students of Uniderp, in Campo Grande, MS, from several areas of knowledge: agrarian (agronomy and veterinary), engineering (mathematics, environmental, civil, computing and electrical engineering) and health (biomedicine, nursing, nutrition), considered as the object of the study in the evaluation of their ecological and anthropological attitudes. The respondents self-completed the questionnaire, instructed only under the object of the research, not being presented the concepts and definitions, hoping that the score on the NEP scales would emerge with expontaneity of their cultural and environmental domain. A total of 256 questionnaires were obtained. After analyzing the data offered by the questionnaires, 241 complete questionnaires were used and included in the analysis.

The sample size was compared with the use of the criteria proposed by Sarstedt and Mooi (2018), who recommend adopting the power of the test of at least 0.80 , a effect size of 0.15 and significance of $\mathrm{p}=0.05$, two-tailed. A priori the sample calculated with the software G*Power (Faul et al., 2007), was evaluated in 68 individuals to be interviewed. This result reinforces that the 241 interviewees are sufficient for the structural models of analysis, estimating, later, a power of the test high to 0.95 (Memon et al., 2020).

The data was analyzed using descriptive statistical techniques to evaluate the interviewees' profiles, mean values, standard deviation and correlations of items and constructs. The consistency of internal reliability was verified by Cronbach's alpha and the proposed structural models for two forced factors (Dunlap et al., 2000) were verified by exploratory factor analysis (EFA) methods (Hair et al., 2010) and confirmatory factor analysis (CFA), with the modeling of structural equations based on covariances (Byrne, 2016). For this, the software SPSS v.26 and AMOS v.24 were used.

\section{Results and Discussion}

The main characteristics of the university students were condensed and are presented in Table 1. 
Table 1. Sample demographics.

\begin{tabular}{|c|c|c|c|c|c|c|c|}
\hline & & \multicolumn{4}{|c|}{ Gender } & \multirow{2}{*}{\multicolumn{2}{|c|}{ Total }} \\
\hline & & \multicolumn{2}{|c|}{ Female } & \multicolumn{2}{|c|}{ Male } & & \\
\hline & & $\mathrm{N}$ & $\%$ & $\mathrm{~N}$ & $\%$ & $\mathrm{~N}$ & $\%$ \\
\hline \multirow[t]{4}{*}{ Age range (years) } & $<19$ & 25 & 28,1 & 37 & 24,5 & 62 & 25,8 \\
\hline & 19 to 22 & 24 & 27,0 & 48 & 31,8 & 72 & 30,0 \\
\hline & 23 to 26 & 21 & 23,6 & 37 & 24,5 & 58 & 24,2 \\
\hline & $>26$ & 19 & 21,3 & 29 & 19,2 & 48 & 20,0 \\
\hline \multirow[t]{3}{*}{ Area of knowledge } & Agricultural & 28 & 31,5 & 75 & 49,7 & 103 & 42,9 \\
\hline & Engineering & 27 & 30,3 & 69 & 45,7 & 96 & 40,0 \\
\hline & Health & 34 & 38,2 & 7 & 4,6 & 41 & 17,1 \\
\hline \multirow[t]{2}{*}{ Semester } & 1 to 3 & 50 & 58,1 & 86 & 57,3 & 136 & 57,6 \\
\hline & 4 to 10 & 36 & 41,9 & 64 & 42,7 & 100 & 42,4 \\
\hline \multirow[t]{2}{*}{ Period } & Daytime & 42 & 48,8 & 33 & 22,0 & 75 & 31,8 \\
\hline & Nighttime & 44 & 51,2 & 117 & 78,0 & 161 & 68,2 \\
\hline
\end{tabular}

Source: Search data,

The NEP structure, with 15 items proposed by Dunlop et al. (2000), was first verified with the use of Cronbach's alpha, as a measure of the internal reliability coefficient of the scale. When processing internal reliability, it suggested the removal of NEP1 and NEP6 from the NEP structure, causing Cronbach's alpha values to approach 0.70, the lower limit accepted (Hair et al., 2010). Then, exploratory factor analysis (EFA) was performed, with varimax rotation, deciding on the forced option for two factors related to ECO and ANTRO, the values found are presented in Table 2.

Table 2. Mean, standard deviation, cumunalities and factor loadings of exploratory factor analysis (EFA), with varimax rotation, of NEP model.

\begin{tabular}{|c|c|c|c|c|c|c|}
\hline Item & Item declaration & $\mathrm{m}$ & $\overline{\mathrm{sd}}$ & Cum & $\overline{\mathrm{ECO}}$ & ANTRO \\
\hline NEP1 & $\begin{array}{l}\text { We're approaching the limit of the number of people the Earth } \\
\text { can support. }\left(^{*}\right)\end{array}$ & 4,4 & 1,80 & 0,10 & 0,32 & 0,02 \\
\hline NEP2 & $\begin{array}{l}\text { Human beings have the right to modify the natural environment } \\
\text { to suit their needs. }\end{array}$ & 3,3 & 1,98 & 0,37 & $-0,10$ & 0,60 \\
\hline NEP3 & $\begin{array}{l}\text { When humans interfere in nature, it often produces disastrous } \\
\text { consequences. }\end{array}$ & 6,0 & 1,66 & 0,51 & $\mathbf{0 , 7 0}$ & $-0,16$ \\
\hline NEP4 & $\begin{array}{l}\text { Human talent will ensure that we do not convert the Earth } \\
\text { uninhabitable. }\end{array}$ & 3,8 & 1,77 & 0,35 & 0,06 & 0,59 \\
\hline NEP5 & Humans are seriously abusing the environment. & 6,1 & 1,52 & 0,51 & 0,69 & $-0,16$ \\
\hline NEP6 & $\begin{array}{l}\text { The Earth has planty of natural resources and we just have to } \\
\text { learn how to use them. }(*)\end{array}$ & 6,1 & 1,53 & 0,18 & 0,42 & 0,07 \\
\hline NEP7 & Plants and animals have as much right to exist as humans. & 6,3 & 1,35 & 0,43 & 0,62 & $-0,22$ \\
\hline NEP8 & $\begin{array}{l}\text { The balance of nature is strong enough to cope with the impacts } \\
\text { of modern industrial countries. }\end{array}$ & 2,6 & 1,76 & 0,36 & $-0,16$ & 0,58 \\
\hline
\end{tabular}




\begin{tabular}{|c|c|c|c|c|c|c|}
\hline NEP9 & $\begin{array}{l}\text { Despite our special abilities, human beings are still subject to the } \\
\text { laws of nature. }\end{array}$ & 6,0 & 1,34 & 0,21 & $\mathbf{0 , 4 6}$ & $-0,01$ \\
\hline NEP10 & $\begin{array}{l}\text { Humanity's so-called "ecological crisis" has been greatly } \\
\text { exaggerated. }\end{array}$ & 3,7 & 2,09 & 0,42 & $-0,05$ & 0,65 \\
\hline NEP11 & Earth is like a spaceship with very limited space and resources. & 4,4 & 2,08 & 0,22 & $\mathbf{0 , 4 2}$ & 0,22 \\
\hline NEP12 & Humans were created to dominate the rest of nature. & 2,9 & 2,05 & 0,44 & $-0,06$ & $\mathbf{0 , 6 6}$ \\
\hline NEP13 & The balance of nature is very delicate and easy to be disturbed. & 5,0 & 1,89 & 0,29 & $\mathbf{0 , 5 3}$ & $-0,04$ \\
\hline NEP14 & $\begin{array}{l}\text { Humans will learn enough about how nature works to be able to } \\
\text { control it. }\end{array}$ & 3,8 & 1,95 & 0,32 & 0,02 & $\mathbf{0 , 5 7}$ \\
\hline NEP15 & $\begin{array}{l}\text { If things continue on the current course, we will soon have a } \\
\text { major ecological catastrophe. }\end{array}$ & 5,6 & 1,81 & 0,53 & 0,69 & $-0,23$ \\
\hline NEP & All declarations & 4,6 & 0,70 & - & - & - \\
\hline \multicolumn{2}{|c|}{ Eigenvalues } & & & & 3,14 & 1,92 \\
\hline \multicolumn{2}{|c|}{ Percentage of variance } & & & & 20,50 & 18,44 \\
\hline \multicolumn{2}{|c|}{ Cronbach' Alpha } & 0,71 & & & 0,70 & 0,68 \\
\hline
\end{tabular}

Legend: $\mathrm{m}$ - mean; sd - standard deviation; Cum - commonality; ECO - factorial loads of ecocentrism attitude; ANTRO - factorial loads of anthropocentric attitude; (*) statement excluded at the suggestion of Cronbach's alpha and by commonalities $<0.20$.

Source: Search data.

In a second moment, the commonalities of NEP variables were evaluated, such as the total variance that an original variable share with the other variables included in the analysis. Despite the recommendation of Hair et al. (2010) to adopt the commonality of $\geq 0.50$ as a guideline, we chose to consider most of the variables proposed by the Dunlop et al. (2000) model with two factors. With this, only the variable NEP1 and NEP6 were removed, because they presented commonalities lower than 0.20. These two were also recommended for their withdrawals by consideration of Cronbach's alpha.

With NEP now with 13 items, a new processing of the EFA was carried out, with varimax rotation, with two factors (Table 2), and the Bartlett's efficity tests $(\mathrm{p}<0.001)$ and the KMO index to establish the pertinence of the EFA $(0.756)$, indicated an adjusted and appropriate model. The forced EFA for two factors, the ECO factor, with seven items, explained $20.50 \%$ of the variance, while the ANTRO factor with six items explained $18.44 \%$ of the variance, accumulating a variance of the two factors of $38.94 \%$. With the modified NEP scale, the internal consistency measured by Cronbach's alpha coefficient obtained a value for the one-dimensional NEP scale of 13 items $\alpha=0.71$, for the ECO scale of seven items $\alpha=0.70$ and for ANTRO scale of six items $\alpha=0.69$, close to the threshold of $\alpha \geq 0.70$. Moyano-Diaz and Polomo-Vélez (2014), Amburgey and Thoman (2012), Guedes et al. (2012) and Erdogan (2009) reported finding $\alpha<0.70$ in NEP model validity, in other places and cultures.

Then, a Confirmatory Factor Analysis (CFA) was conducted for the two forced factors with 13 items found in the EFA (Figure 1). The adjustment indexes of the CFA structural model were obtained. As a global adjustment, $\chi 2=103.08$, with 64 degrees of freedom, $\mathrm{p}<0.001$ and $\chi^{2} / \mathrm{gl}=1.611$ ratio, for the sample of 241 respondents, indicated that there is no significant difference between the observed and expected covariance matrices of the model. 
Figure 1. Structural model for confirmatory factor analysis of NEP with two factors.

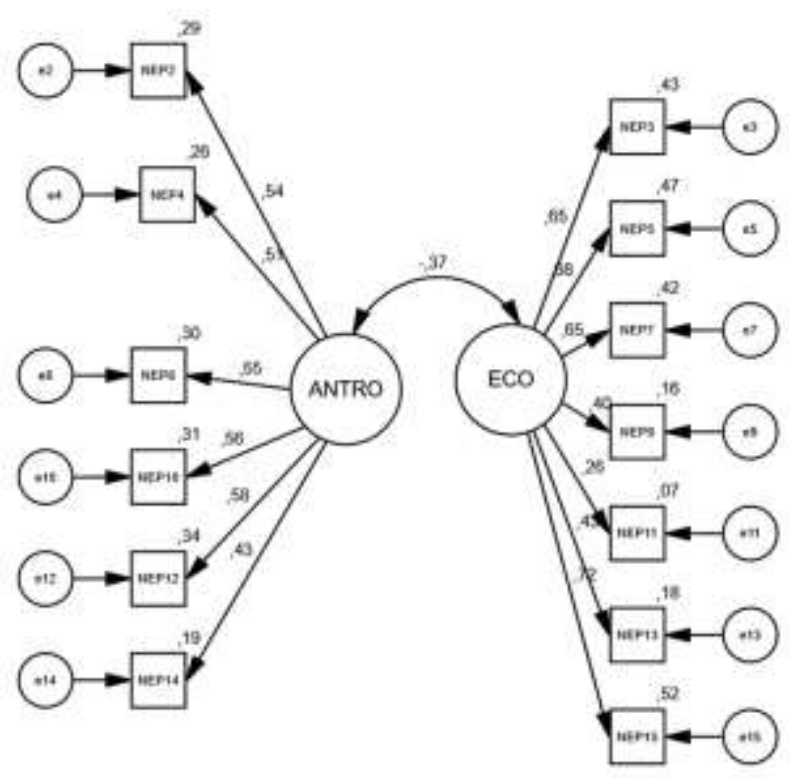

Source: Authors.

We also obtained the root mean square error of approximation index (RMSEA $=0.051$ ), the goodness-of-fit index (GFI=0.934), and the comparative fit index ( $\mathrm{CFI}=0.735)$. These indexes are among the limits recommended by Hair et al. (2010) and Byrne (2016) and indicated the appropriate fit of the two-factor model. A negative correlation coefficient of 0.37 was obtained between ECO and ANTRO, considered as a mean intensity value (Cohen et al., 2009).

With these results and adjustment indexes, the proposed model of two forced factors of Dunlop et al. (2000), was considered as adequate and confirmed the theory of the proposed measurement scale. The correlation of -0.37 is an indication of consistency of the two-factor ECO and ANTRO model, partly explaining that the increase of one of the two factors can cause the decrease of the other. Thus, for example, with the increase in the ECO of a population, the ANTRO should decrease.

Next, we evaluated the possible existence of differences in groups of gender, age, and area of knowledge in relation to the factors ECO and ANTRO of NEP. First, the normality test was verified with the use of Kolmogorov-Smirnov (K-S) statistics for the factors ECO and ANTRO, considering the data of the 241 respondents. The normality of ECO (K-S $=0.107$, $\mathrm{p}<0.001)$ and ANTRO (K-S $=0.073, \mathrm{p}<0.003)$ was not found. Therefore, we opted for the nonparametric techniques of the Kruskal-Wallis test to compare the scores between more than two independent groups (age and knowledge area), and MannWhitney $\mathrm{U}$ test, for the difference test between two independent groups: gender (female or male), semester (1st - 3rd. Semester or 4th. - 10th. semester) and period (day or night), evaluating the respective medians (md). Table 1 shows the characteristics and segmentations of each of the groups analyzed.

The Kruskal-Wallis test used to verify differences in attitudes between ECO and ANTRO, by age group, revealed that there are no significant differences between the groups of the four age groups, $p<0.05$. That is, it cannot be inferred that due to the age group, different attitudes can be distinguished in relation to ECO and ANTRO. However, when the factors for all age ranges are evaluated, the ECO attitude $(\mathrm{md}=5.9)$ is greater than ANTRO $(\mathrm{md}=3.2)$, indicative of a more ecocentric attitude, compared to the anthropocentric attitude.

When the existence of significant differences in attitudes between the factors ECO and ANTRO was analyzed, considering the three groups of the knowledge areas, the Kruskal-Wallis test indicated that there were no significant differences in $\mathrm{p}<0.05$ for the ECO factor $(\chi 2=1.92, \mathrm{gl}=2$, and $\mathrm{p}=0.383)$, in the three areas of knowledge: agrarian ( $\mathrm{md}=5.7)$, engineering $(\mathrm{md}=5.8)$, and health $(\mathrm{md}=6.1)$. For the ANTRO factor, the test indicated the significant difference for the three 
knowledge areas $(\chi 2=8.91, \mathrm{gl}=2$, and $\mathrm{p}=0.012)$. The results indicated the medians for health students $(\mathrm{md}=2.8)$, for engineering area $(\mathrm{md}=3.2)$ and for agrarian area $(\mathrm{md}=3.5)$. These results revealed that health academics are slightly more proenvironment than other of engineering and agrarian. What can be assumed is that the more ecocentrist view of health students is associated with the very structure of humanist university education and preservation. However, the results of medians presenting values lower than 4.0, which is indicative that they have more ecological attitudes and less support for the dominant social paradigm (DSP).

With the application of the Mann-Whitney $\mathrm{U}$ test, to investigate differences in attitudes between the classification of respondents regarding gender, it was found that there are no differences for the ECO attitude for the male (md=5.7) and female $(\mathrm{md}=5.9)$ groups, with the indicators of the $\mathrm{U}=6,031.0, \mathrm{z}=-1.33$ and $\mathrm{p}=0.18$. For ANTRO attitude, the Mann-Whitney $\mathrm{U}$ test indicated the existence of independent samples $(\mathrm{U}=8,119.0, \mathrm{z}=2.70$ and $\mathrm{p}=0.01)$. For the male group presented a $\mathrm{md}=3.5$ and the female group $m d=3.0$. It appears that women are more pro-environment than men. These results are supported by what was found in McCright (2010), in which it reports that American women were more concerned about climate change than men. Also, Costache and Sencovivi (2019), with a similar study in Romania, indicated that women were more oriented to proenvironmental, proposing their explanation due to their role as nourisher. Moyano-Dias and Palomo-Vélez (2014), in research with the Chilean population, found that men are more ecocentric than women, in addition Ibrahim and Ibrahim (2018), in a study of Nigerian undergraduates reported that there are no differences in environmental attitudes between men and women.

As ECO and ANTRO relations, when analyzed by range of the semester in which he is attending the university (first to Third semester and whatarto to the tenth semester), the Mann-Whitney U nonparametric test revealed not submit significant differences between semesters. For the results ECO among the academics of the 1st. -3 rd. semesters $(\mathrm{md}=5.9)$ and for those in the 4th. - 10th. ( $\mathrm{md}=5.9$ ), with $\mathrm{U}=7,114.5, \mathrm{z}=0.18$ and $\mathrm{p}=0.86$, and and andm in relation to the ANTRO, the results for the students of the 1st. - 3 rd. semesters $(m d=4.8)$ and for those in the 4th. -10 th. $(m d=4.7)$, with $\mathrm{U}=6,819.5, \mathrm{z}=-0.38$ and $\mathrm{p}=0.71$, which are indications of no significant differences at the two-tailed level of $p<0,05$.

When analyzing the existence of significant differences between the course period (day or night), by the same MannWhitney $\mathrm{U}$ test, it reported that it cannot be affirmed that there are differences for ECO and ANTRO attitudes. The results presented were for the ECO of the students attending during the daytime ( $\mathrm{md}=5.7)$ and nighttime ( $\mathrm{md}=5.9$ ), with $\mathrm{U}=6,407.0$, $\mathrm{z}=0.09$ and $\mathrm{p}=0.92$. For the ANTRO, the results were for the daytime $(\mathrm{md}=4.8)$ and nighttime $(\mathrm{md}=4.8)$, with $\mathrm{U}=5,937.5, \mathrm{z}=-$ 0.84 and $\mathrm{p}=0.40$.

Works by Lima et al. (2015) and Telocken et al. (2017) presented results of research with undergraduates, in relation to consumption awareness, and did not identify different environmental attitudes when segmented by semester ranges and course period. Although the reports are studies of frequency observed in scales of attitudes, without statistical tests of significance of differences, we consider here as results that approximate what was found in this research.

The authors recognize that as all scientific and empirical studies, certain limitations cannot be considered. The sample of this research was extracted from the university population of the HEI for convenience. A small group of face-to-face undergraduate courses was reached, within the portfolio offered, in various areas of knowledge. The authors are aware that this can cause a bias in the generalized results and in the restriction of inferences of environmental attitudes, broader, for the other university students of the HEI.

At the same time, it is considered that the findings in this study provide interesting information about the behavior of university students in relation to the environment and demonstrates more pro-environment attitudes.

Future studies can be expanded and seek to assess the consistency of the NEP scale. As in this study, the confirmation of the model was performed for two forced factors, and Dunlap et al. (2000) also describe that NEP can be deployed into five factors, considering other studies with different results, reinforcing the opinion of extending the study. Whitmarsh (2008), 
describes the existence of difficulties for the interviewees to interpret some statements for environmental events and suggests that this scale be evaluated and validated as a predictor of environmental behavior. In the follow-up, it is proposed that the NEP scale be used to evaluate the change in behavior of university students, when submitted to environmental education, or other people under the environmental view to tourism, reducing environmental impacts, among others.

All authors executed their parts cooperatively throughout the process of conception, methodology, analysis, discussion, and preparation of the article. The authors state that the research with university students met ethical standards and confidentiality and claim that there is no conflict of interest.

\section{Conclusion}

The confirmatory factor analysis allowed admitting the structural model as able to evaluate the ECO and ANTRO of the academics of the HEI, as proposed by Dunlap et al. (2000), even with the reduction to 13, of the 15 original declarations. The results by groups indicated that the students segmented by gender did not present significant differences for the ECO factor, but for the ANTRO. Women are more pro-environment than men.

There were no significant differences for the segmentations regarding the range of the semester, nor for the course period, for both ECO and ANTRO factors.

When assessing the segmentations by area of knowledge, there is no difference for the ECO attitude. However, for the ANTRO attitude, the health area is less anthropocentric. As a broader result, it can be said that the model indicates that HEI academics are more ecocentric.

\section{Acknowledgments}

The authors would like to thank the Stricto Sensu Programs and the coordinators of the undergraduate courses, at UNIDERP, for their support in carrying out this research when receiving financial, personnel and infrastructure support. Also, we wish to thank to the RDS editor and the two anonymous referees for their useful comments on an earlier draft of this manuscript.

\section{References}

Amburgey, J. W., \& Thoman, D. B. (2012). Dimensionality of the New Ecological Paradigm: Issues of Factor Structure and Measurement. Environment and Behavior, 44(2), 235-256. 10.1177/0013916511402064.

Anderson, M. W. (2012). New ecological paradigm (NEP) scale. In I. Spellerberg, The Berkshire encyclopedia of sustainability: Measurements, indicators, and research methods for sustainability. $6,260-262$.

Barros, M. V., Puglieri, F. N., Tesser, D. P., Kuczynski, O., \& Piekarski, C. M. (2020). Sustainability at a Brazilian university: developing environmentally sustainable practices and a life cycle assessment case study. International Journal of Sustainability in Higher Education, 21(5), 841-859. 10.1108/IJSHE-102019-0309

Brundtland, G. H. (1988). Comissão Mundial Sobre Meio Ambiente E Desenvolvimento - 1988. Nosso Futuro Comum (Relatório Brundtland). Fundação Getúlio Vargas.

Byrne, B. M. (2016). Structural Equation Modeling with Amos (3th ed.). Routledge.

Cohen, J., Cohen, P., West, S. G., \& Aiken, L. S. (2009). Applied Multiple Regression/Correlation Analysis for the Behavioral Science (3rd ed.). Routledge.

Costa, L. F., Neumann, S. E., Dorion, E. C., Olea, P., \& Severo, E. A. (2019). Sustentabilidade e Desenvolvimento Sustentávelno Contexto das Ciências Sociais: do século XVIII ao século XXI. Revista Metropolitana de sustentabilidade, 9(2), 6-19.

Costache, A., \& Sencovivi, M. (2019). Age, Gender And Endorsement Of The New Ecological Paradigm. International Multidisciplinary Scientific GeoConference, 19, 11-22. 10.5593/sgem2019/5.1/S20.002

Dunlap, R. E. (2008). The new environmental paradigm scale: From marginality to worldwide use. Journal of Environmental Education, 40(1), 3-18. 
Dunlap, R. E., \& Van Liere, K. D. (1978). The New Environmental Paradigm. Journal of Environmental Education, 9(4), 10-19. 10.1080/00958964.1978.10801875

Dunlap, R. E., Van Liere, K. D., Merig, A. G., \& Jones, R. E. (2000). Measuring endorsement of the New Ecological Paradigm: A revised NEP Scale. Journal of Social Issues, 56(3), 425-442.

Edorgan, N. (2009). Testing the new ecological paradigm scale: Turkish case. African Journal of Agricultural Research, 4(10), 1023-1031.

Faber, N., Jorna, R., \& Van Engelen, J. (2005). The Sustainability of "sustainability": a study into the conceptual foundations of the notion of "sustainability". Journal of Environmental Assessment and Management, 7(7), 1-33.

Faul, F., Erdfelder, E., Lang, A. G., \& Buchener, A. (2007). G*Power 3: A flexible statisitical power analysis program for social, behavioral, and biomedical sciences. Behavior research methods, 39(2), 175-191.

Gerhardt, T. E., \& Silveira, D. T. (2009). Métodos de Pesquisa. Editora da UFRGS. Retrived from http://hdl.handle.net/10183/52806.

Giddy, J. K., \& Webb, N. L. (2018). Environmental attitudes and adventure tourism motivations. GeoJournal, 83, 275-287. 10.1007/s10708-017-9768-9

Guedes, G. R., Hora, A. M., \& Dias, C. A. (2012). Atitude e Valores Ambientais em Contexto de Baixo Desenvolvimento Humano: avaliação crítica da Escala do Novo Paradigma Ecológico (NEP). XVIII Encontro Nacional de Estudos Populacionais (1-18). Águas de Lindóia: ABEP.

Hair Jr, J. F., Black, W. C., Babin, B. J., \& Anderson, R. E. (2010). Multivariate Data Analysis (7th ed.). Prentice Hall.

Holden, E., Linnerud, K., \& Banister, D. (2017). The Imperatives of Sustainable Development. Sustainable Development, 25(3), 2013-226. 10.1002/sd.1647

Hsu, J. L., \& Lin, T. Y. (2015). Carbon reduction knowledge and environmental consciousness in Taiwan. Management of Environmental Quality, 26(1), 3752. 10.1108/MEQ-08-2013-0094

Hunter, L. M., \& Rinner, L. (2004). The association between environmental perspective and knowledge and concern with species diversity. Society and Natural Resources, 17(6), 517-532. 10.1080/08941920490452454

Ibrahim, F. M., \& Ibrahim, B. A. (2018). Gender and economic orientation as correlates of attitudes towards environmental abuse: A study of a group of Nigerian undergraduates. Environmental \& Socio-economic Studies, 6(1), 17-24. 10.2478/environ-2018-0003

Kim, H., Borges, M. C., \& Chon, J. (2006). Impacts of environmental values on tourism motivation: The case of FICA, Brazil. Tourism Management, 27, 957967. 10.1016/j.tourman.2005.09.007

Lima, P. H., Ferreira, T. C., Bezerra, Y. M., Feitosa, M. J., \& Gómez, C. R. (2015). Consumo consciente: Um estudo com estudantes do Curso de Administração da Universidade Federal Rural de Pernanbuco, Unidade Acadêmica de Serra Talhada. Revista de Administração, Contabilidade e Economia da FUNDACE, 6(2), 97-108. 10.13059/racef.v6i2.333

Luo, Y., \& Deng, J. (2008). The New Environmental Paradigm and Nature-Based Tourism Motivation. Journal of Travel Research, 46, $392-402$. $10.1177 / 0047287507308331$

McCright, A. M. (2010). The effects of gender on climate change knowledge and concern in the American public. Population and Envrionment, $32(1)$, 66-87. $10.1007 / \mathrm{s} 11111-010-0113-1$

Meadows, D. H., Meadows, D. L., Randers, J., \& Behrens III, W. W. (1973). Limites do crescimento: um relatório para o projeto do Clube de Roma sobre o dilema da humanidade. Perspectiva.

Memon, M. A., Ting, H., Cheah, J. H., Thurasamy, R., Chuah, F., \& Cham, T. H. (2020, June). Sample size for survey research: Review and recomendations. Journal of Applied Structural Equation Modeling, 4(2), 10.47263/JASEM.4(2)01

Mikhailova, I. (2004). Sustentabilidade: evolução dos conceitos teóricos e os problemas de mensuração prática. Revista Econômia e Desenvolvimento, 16, 2241.

Moyano-Dias, E., \& Palomo-Vélez, G. (2014). Propriedades Psicométricas de la Escala Nuevo Paradigma Ecológico (NEP-R) en Población Chilena. Psico, 45(3), 415-423.

Nascimento, L. F. (2008). Gestão Ambiental e Sustentabilidade. Universidade Aberta do Brasil.

Nossa, V., Rodrigues, V. R., \& Nossa, S. N. (2017). O que se tem pesquisado sobre Sustentabilidade Empresarial e sua Evidenciação? Revista de Educação e Pesquisa em Contabilidade, 11, 87-105. 10.17524/repec.v11i0.1719

Ntanos, S., Kyriakopoulos, G., Skordoulis, M., Chalikias, M., \& Arabatzis, G. (2019). An Application of the New Environmental Paradigm (NEP) Scale in a Greek Context. Energies, 12(2), 1-18. 10.3390/en12020239

Ogunbode, C. (2013). The NEP scale: measuring ecological attitudes/worldviews in an African context. Environment, development and sustainability,, 15(6), 1477-1494. 10.1007/s10668-013-9446-0

Pereira, A. S., Shitsuka, D. M., Parreira, F. J., \& Shitsuka, R. (2018). Metodologia da pesquisa científica. UFSM. https://repositorio. ufsm.br/bitstream/handle/1/15824/Lic_Computacao_Metodologia-Pesquisa-Cientifica. pdf.

Sachs, I. (2008). Desenvolvimento: includente, sustentável e sustentado. Garamond.

Sarstedt, M., \& Mooi, E. (2018). A concise guide to market research: the process, data, and methods using IBM SPSS Statistics. Springer. 
Research, Society and Development, v. 10, n. 4, e16410413947, 2021

(CC BY 4.0) | ISSN 2525-3409 | DOI: http://dx.doi.org/10.33448/rsd-v10i4.13947

Schinaider, A. D., \& Talamini, E. (2019). Consciência ambiental versus atitudes pró-ambientais: Uma avaliação dos proprietários das agroindústrias familiares. Revista Brasileira de Gestão e Desenvolvimento Regional, 15(3), 33-47.

Speer, J. H., Sheets, V., Kruger, T. M., Aldrich, S., P., \& McCreary, N. (2020). Sustainability survey to assess student perspectives. International Journal of Sustaibility in Higher Education, 21(6), 1151-1167. 10.1108/IJSHE-06-2019-0197

Sutton, S. G., \& Gyuris, E. (2015). Optimizing the environmental attitudes inventory: Establishing a baseline of change in students' attitudes. International Journal of Sustentainability in Higher Education, 16(1), 16-33. 10.1108/IJSHE-03-2013-0027

Teixeira, L. I., Silva Filho, J. C., \& Meireles, F. R. (2016). Consciência e Atitude Ambiental em Estudantes de Instituições de Ension Técnico e Tecnológico. Revista Eletrônica em Gestão, Educação e Tecnologia Ambiental, 20(1), 334-350. 10.5902/2236117020025

Telocken, S. G., Garlet, V., Favarin, R., Madruga, L. R., \& Trevisan, M. (2017). O consumo consciente entre os alunos de Administração de uma universidade federal brasileira sob a ótica da educação para a sustentabilidade. Revista de Gestão e Desenvolvimento, 14(1), 100-113.

Utari, E., \& Nadiroh, S. Y. (2016). The students' new environmental paradigm (NEP) of mathematics study program at Universitas Sultan Ageng Tirtayasa in the teaching-learning of envronmental subject. In ISQAE 2016 5th International Seminar On Quality \& Affordable, $214-219$.

Whitmarsh, L. (2008). Are flood victims more concerned about climate change than other people? The role of direct experience in risk perception and behavioural response. Journal of Risk Research, 11(3), 351-374. 10.1080/13669870701552235

Xiao, C., Dunlap, R. E., \& Hong, D. (2019). Ecological Worldview as the Central Component of Environmental Concern: Clarifying the Role of the NEP. Society \& Natural Resources, 32(1), 53-72. 10.1080/08941920.2018.1501529 